\title{
Diversity, Distribution, and Abundance of House Dust Mites on Settlement Region in Bogor
}

\author{
Upik Kesumawati $\operatorname{Hadi}^{1 *}$, Susi Soviana ${ }^{1}$, N Qamariah ${ }^{1}$ \\ ${ }^{1}$ Entomology Laboratory, Division of Parasitology and Medical Entomology, Faculty of Veterinary Medicine, IPB \\ University, Darmaga, Bogor, West Java 16680, Indonesia \\ Corresponding author.Email: upikke@ipb.ac.id
}

\begin{abstract}
The house dust mite (HDM) is a major allergen source and a significant cause of allergic rhinitis and allergic asthma. HDM is commonly found in dust originating from human resident and are mainly found in seats (chairs, sofas, benches), carpets, floors and beds (mattresses, pillows, sheets). This study was conducted on six types of settlements in Bogor, i.e. densely populated residential, residential complexes, guest houses, boarding schools, boarding houses and student dormitories. Dust from all the settlements collected by vacuum cleaner and HDM were then isolated and identified under microscope at laboratory. The result showed there were 10 types of HDM, i.e Blomia tropicalis (45.34\%), Dermatophagoides pteronyssinus (17.45\%), Cheyletidae (15.62\%), Blomia spp. (8.61\%), Mesostigmata (7.17\%), Dermatophagoides farinae (3.67\%), Oribatida $(0.56 \%)$, Acaridae $(0.32 \%)$, Tyrophagus spp. (0.16\%), Lepidoglipus destructor $(0.08 \%)$. The highest density of HDM on housing was found on the carpet, (23.94\%) in densely populated residential and (33.71\%) in residential complex. HDM mostly found on the furniture at guest houses (100\%), boarding schools (37.62\%), boarding houses (52.02\%) and student dormitories (35.17\%). There was significantly correlation between humidity and temperatures against the infestation of HDM in all types of settlements.
\end{abstract}

Keywords: house dust mite, Blomia, Dermatophagoides, allergic, Indonesia

\section{INTRODUCTION}

House dust mites (HDM) are commonly found in dust originating from human habitation and are commonly found in the pillows, sheets, mattresses, sofas, rugs and other home furnishings. HDM found in house dust generally belong to the suborder Astigmata, Prostigmata, Mesostigmata and Cryptostigmata [1, 2]. The major HDM in the climatic area are the Dermatophagoidinae mites, i.e., Dermatophagoides pteronyssinus, D. farinae and $D$. microceras, and members of the subfamily Pyrogliphinae, of which the most common species is Euroglyphus maynei. The Acaridae, i.e., Acarus siro, Tyrophagus putrescentiae, T. longiors, and other mites are found in larders or other food stores, where mites of the family Glycyphagidae, i.e., Lepidoglyphus destructor and Glycyphagus domesticus, also are common [3].

HDM causes asthma that affects millions of people around the world primarily derived from species $D$. pteronyssinus, D. farinae, E. maynei and Blomia tropicalis [4]. The factor that influences the survival of HDM and its prevalence is environmental relative humidities that they are rare or absent in dry conditions. In general, HDM is rarely found in public buildings and modes of transportation than in homes, because HDM could not survive in dry conditions and need sufficient amount of food, they feed on dead skin cells of humans and fungi [5]. HDM species diversity in an urban environment has been reported from several countries [5] and specifically in Asia by Thomas [6]. The first archives of the HDM in Jakarta reported by Baratawidjaja et al. [7] and in Denpasar Bali by Santoso [8], and no informations yet after that.

This study aims to study the diversity, the distribution and density of HDM in the settlement areas in Bogor.

\subsection{Materials and Methods}

\subsubsection{Location and Time Research}

The study was conducted in the residential area of society that is divided into two types of regions, i.e. housing (densely populated residential and residential complexes) and temporary shelter (guest house, boarding schools, boarding houses and student dormitories). HDM identification process was carried out in the Laboratory of Entomology of Health, Faculty of Veterinary Medicine, IPB University, Bogor, Indonesia. This research was conducted from September 2014 - March 2015. 


\subsubsection{House Dust Mites Sampling}

\subsubsection{At housing}

HDM sampling at this place were carried out in (1) densely populated residential (irregular dense cluster housing area i.e. Cibanteng, Babakan Leak and Babakan Raya villages) and (2) residential complexes (the area where a cluster of housing lined up regularly i.e. IPB Housing Complex). 20 houses on each type of housing were examined for the prevalence of HDM. HDM samples were collected by using vacuum cleaner on five points, namely bed (mattress dust, sheets dust, pillow dust), seat (sofas, chairs and benches) carpet, flooring and home furnishings (desks, cabinets, furniture, fans etc). The collected dust samples from every point were taken and put in plastic bags and labelled.

\subsubsection{At transitional shelter}

Sampling of dust in a temporary shelter was done in four types of areas i.e. guest house (two guest houses), Islamic boarding schools (male and female dormitory), boarding houses (male and female boarding house), student dormitories (male and female dormitory) closest to the campus area of IPB University Bogor. Dust sampling was conducted at $30 \%$ of the number of available rooms at each study site, and the dust was collected at three points within each room, namely on the floor, the bed (sheets dust, pillow dust, mattress dust, beds dust) and furnishings.

\subsubsection{Isolation and Identification of $H D M$}

Isolation of HDM was done by putting $1 \mathrm{~g}$ dust into the Berlese funnel [9] in 30 minutes. The collected HDM was examined under a microscope and counted by using a needle. Furthermore, the HDM preparations were made on the microscope slide using Hoyer medium or Canada balsam [9]. Identification was done by using identification keys of Collof and Spieksma, Krantz and Walter, and Roden $[1,2,10]$.

\subsubsection{Data analysis}

HDM species diversity including data on relative abundance, the frequency of species, dominance of species was analysed and the Shannon-Wiener diversity index $(\mathrm{H})$ followed the formula according to Odum [11].

$$
(H)=-\sum P_{i} \ln \left(P_{i}\right) ; \text { with } P_{i}=N_{i} / N
$$

Where:

$\mathrm{P}_{\mathrm{i}}$ : Comparison of the number of individuals of a species with an overall species

$\mathrm{N}_{\mathrm{i}} \quad$ : the number of individuals to-i

$\mathrm{N}$ : The total number of individuals

Criteria is the diversity index followed Krebs [12]: High $(\mathrm{H}>3)$; Moderate $(1 \leq \mathrm{H} \leq 3)$; Low $(\mathrm{H}<1)$ [12].

Humidity and temperature data obtained from BMKG Bogor, The Meteorology, Climatology and Geophysics Agency [13] inputted into the database using SPSS 16. The non-parametric statistics (Spearman Correlation Test) to determine the relationship of the humidity and temperature of the HDM infestation. The level power relations are no association/weak $(\mathrm{R}=0.00-0.25),(\mathrm{R}=$ $0.26-0.50)$, strong $(\mathrm{R}=0.51-0.75)$, and very strong/ perfect $(\mathrm{R}=0.76-1.00)$.

\subsection{Our Contribution}

This paper presents some informations on diversity, distribution and abundance of house dust mite infestations in six types of settlements in Bogor Indonesia, i.e. densely populated residential, residential complexes, guest houses, boarding schools, boarding houses and student dormitories. The correlation between humidity and temperatures against the infestation of HDM in all types of settlements were also described in this paper.

\subsection{Paper Structure}

The rest of the paper is organized as follows: Section 2 described the diversity of types of HDM, the relative abundance and species dominance of HDM, the density and distribution of HDM at housing areas, and the density and distribution of HDM at the transitional shelter areas. Finally, Section 3 concludes the paper and presents directions for future studies.

\section{RESULTS AND DISCUSSION}

\subsection{The Diversity of HDM Types}

The type and the percentage of HDM found in the settlements showed varying results as shown in Table 1. The HDM found in densely populated housing, mostly was Blomia tropicalis $(48.18 \%)$, followed by Dermathophagoides pteronyssinus (11.66\%), Cheyletidae (10.13\%), Blomia sp. (13.58\%), Mesostigmata (9.75\%), D. farinae $(5.35 \%)$, Pseudoscorpion $(1.15 \%)$ and Oribatellidae $(0.19 \%)$. Meanwhile, there were 8 types of HDM found in a residential complex i.e. B. tropicalis (44.42\%), followed by Cheyletidae (23.95\%), D. 
pteronyssinus (21.63\%), Blomia sp. (4.65\%), Mesostigmata $(2.33 \%), \quad D . \quad$ farinae $(0.93 \%)$ Pseudoscorpion $(0.93 \%)$, Oribatidae $(0.70 \%)$ and Tyrophagus spp. $(0.47 \%)$. Also, there were 8 types of HDM found in the temporary residence of student i.e. B. tropicalis (41.53\%), D. pteronyssinus (21.59\%), Cheyletidae (12.96\%), Blomia sp. (5.65\%), Mesostigmata (9.63\%), D. farinae (4.65\%), Acaridae (1.33\%), Oribatidae (1.00\%), Pseudoscorpion (1.00\%) and Lepidoglyphus destructor $(0.66 \%)$. However, there were only two types of HDM found in the guest house i.e. B. tropicalis $(50 \%)$ and Cheyletidae $(50 \%)$.

In this study, a total of 11,298 HDM from $534 \mathrm{~g}$ dust samples were collected from six locations in Bogor. Of 10 HDM species found were classified into one Class Arachnida, 4 different suborders (i.e. Astigmata, Prostigmata, Mesostigmata and Oribatida) and 5 families i.e., Glycyphagidae (B. tropicalis, Blomia $\mathrm{sp}, L$. destructor), Pyrogliphidae (D. pteronyssinus and $D$. farinae), Acaridae (Tyrophagus spp.), Cheyletidae, and Oribatidae. These results were different to that found by Baratawidjaja et al. [7] 7 types of HDM namely, D. pteronyssinus, D. farinae, B. tropicalis, Sturnophagoides sp, Tyrophagus putrescentiae, Austroglycyphagus sp and Cheyletus sp were found in Jakarta. In this study, there were no finding of Sturnophagoides $\mathrm{sp}$ and Austroglycyphagus sp instead another type of HDM ( $L$. destructor) was found.

Blomia tropicalis was detected in all types of settlements, found in carpets, beds, seats, floor and household furniture. This species was commonly known as a causing agent of asthma and rhinitis. $62 \%$ of asthma patients have positive allergen against $B$. tropicalis and $38 \%$ of patients positive against $D$. farinae and $D$. pteronyssinus [14].

Dermatophagoides pteronyssinus was found in densely populated areas, residential complexes and temporary residence of students. This mite found in carpets, bedding, seating, flooring and home furnishings. This species is commonly found in homes and distributes worldwide [15]. This mite can complete its life cycle in temperature 16-35 ${ }^{\circ} \mathrm{C}$, from egg to adult takes approximately 20 days [16]. The adult male mites live for about 77 days while females 45 days, and the females can produce 40-80 eggs during her lifetime [17].

Dermathophagoides farinae was found in a densely populated residential, residential complexes and temporary student residences. According to Larry et al. [18] the temperature range for optimum development of $D$. farinae is between $23-30{ }^{\circ} \mathrm{C}$. These mites can complete its life cycle for 28 days at a temperature of $23^{\circ} \mathrm{C}$, and 20 days at $30{ }^{\circ} \mathrm{C}$. This mite reproduction period at a temperature of $23{ }^{\circ} \mathrm{C}$ was 24 days and can lay 1 to 4 eggs a day, and can produce 40-80 eggs during their lifespan. The eggs are unable to hatch when the temperature above $30^{\circ} \mathrm{C}$. D. farinae has a cosmopolite distribution that likes $75 \%$ of humidity [19]. Females may live longer (about 100 days) than other HDM types [20].

Family Cheyletidae found in all types of settlements. This study found Cheyletidae mite mixed with other dust mites and many were found in the living room on a couch, floor and carpet. According to Danny et al. [21] Cheyletiella caused cheyletiellosis or "walking dandruff" in dogs and cats with variably pruritic and non-seasonal. These mites do not burrow but live in keratin of skinsurface. They move rapidly but periodically attach firmly to the epidermis, pierce the skin with their chelicerae, and become engorged with tissue fluids. The eggs are smaller than louse nits and are attached to hairs by fine fibrillar strands.

Table 1 The number and percentage of house dust mites on settlements in Bogor from October 2014-February 2015

\begin{tabular}{|l|l|c|c|c|c|c|}
\hline \multirow{2}{*}{ No } & \multirow{2}{*}{ Type of mite } & \multicolumn{3}{|c|}{ Location-type settlements } & \multirow{2}{*}{ Total } \\
\cline { 3 - 7 } & & $\mathbf{A} \sum(\boldsymbol{\%})$ & $\mathbf{B} \sum(\boldsymbol{\%})$ & $\mathbf{C} \sum(\boldsymbol{\%})$ & $\mathbf{D} \sum(\boldsymbol{\%})$ & \\
\hline 1 & Blomia tropicalis & $252(48.1)$ & $191(44.4)$ & $125(41.5)$ & $1(50)$ & 569 \\
\hline 2 & Dermathophagoides pteronyssinus & $61(11.6)$ & $93(21.6)$ & $65(21.5)$ & $0(0)$ & 219 \\
\hline 3 & Cheyletidae & $53(10.1)$ & $103(23.9)$ & $39(12.9)$ & $1(50)$ & 196 \\
\hline 4 & Blomia Spp & $71(13.5)$ & $20(4.65)$ & $17(5.65)$ & $0(0)$ & 108 \\
\hline 5 & Mesostigmata & $51(9.75)$ & $10(2.33)$ & $29(9.63)$ & $0(0)$ & 90 \\
\hline 6 & Dermathophagoides farinae & $28(5.35)$ & $4(0.93)$ & $14(4.65)$ & $0(0)$ & 46 \\
\hline 7 & Oribatidae & $1(0.19)$ & $3(0.70)$ & $3(1.00)$ & $0(0)$ & 7 \\
\hline 8 & Acaridae & $0(0.00)$ & $0(0.00)$ & $4(1.33)$ & $0(0)$ & 4 \\
\hline 9 & Tyrophagus spp & $0(0.00)$ & $2(0.47)$ & $0(0.00)$ & $0(0)$ & 2 \\
\hline 10 & Lepidoglyphus destructor & $0(0.00)$ & $0(0.00)$ & $2(0.66)$ & $0(0)$ & 2 \\
\hline 11 & Pseudoscorpion* & $6(1.15)$ & $4(0.93)$ & $3(1.00)$ & $0(0)$ & 13 \\
\hline Total & & $\mathbf{5 2 3 ( 1 0 0 )}$ & $\mathbf{4 3 0 ( 1 0 0 )}$ & $\mathbf{3 0 1}(\mathbf{1 0 0})$ & $\mathbf{2}(\mathbf{1 0 0})$ & $\mathbf{1 2 5 6}$ \\
\hline
\end{tabular}

Note: (A) Densely populated residential area, (B) Residential complex, (C) Temporary student residence, (D) Guest house, $\left(^{*}\right)$ Not a group of mites 


\subsection{The Relative Abundance and Species Dominance of HDM}

The relative abundance and dominance value of HDM in Bogor were showed in Table 2. Blomia tropicalis and Cheyletidae were always obtained (the frequency value 1.00) which means these HDM were discovered at all types of settlements. Based on species dominance, HDM in Bogor residential area was dominated by $B$. tropicalis (45.30\%), followed by $D$. pteronyssinus (13.08\%), Cheyletidae (15.61\%), Blomia spp. (6.45), Mesostigmata $(5.37 \%)$, D. farinae $(2.75 \%)$, Oribatellidae $(0.42 \%)$, Acaridae $(0.08 \%)$, Tyrophagus spp $(0.04 \%)$ and $L$. destructor $(0.04 \%)$. The species diversity index of HDM in residential areas of Bogor was medium category (1589).

\subsection{The Density and Distribution of HDM at Housing Areas}

The density and distribution of HDM in the housing areas are presented in Table 3. The highest density of HDM at household furniture in Bogor was found distributed in carpets, both in densely populated residential ( $23.94 \%$ with average $73 \pm 61.69$ mites per g dust) and in residential complex $(33.71 \%$ with average $51.88 \pm 43.52$ mites per g dust). As many 11 carpets and 9 carpets in both areas were examined and all positive infested with HDM $(100 \%)$. The temperature at the time of sampling was $26.9{ }^{\circ} \mathrm{C}$ and $86 \%-88 \%$ of relative humidity.

Furthermore, the percentage of HDM in beds was also detected both in densely populated residential (80\%)

Table 2 Relative abundance and dominance Figures House Dust Mites in Bogor settlements from October 2014 February 2015

\begin{tabular}{|l|c|c|c|}
\hline Type & Relative abudance (\%) & Frequency & Species dominance (\%) \\
\hline B. tropicalis & 45.30 & 1.00 & 45.30 \\
\hline D. pteronyssinus & 17.44 & 0.75 & 13.08 \\
\hline Cheyletidae & 15.61 & 1.00 & 15.61 \\
\hline Blomia Spp & 8.60 & 0.75 & 6.45 \\
\hline Mesostigmata & 7.17 & 0.75 & 5.37 \\
\hline D. farinae & 3.66 & 0.75 & 2.75 \\
\hline Oribatidae & 0.56 & 0.75 & 0.42 \\
\hline Acaridae & 0.32 & 0.25 & 0.08 \\
\hline Tyrophagus spp & 0.16 & 0.25 & 0.04 \\
\hline L. destructor & 0.16 & 0.25 & 0.04 \\
\hline Pseudoscorpion & 1.04 & 0.75 & 0.78 \\
\hline
\end{tabular}

Table 3 The density and distribution of HDM at the housing area of Bogor from October 2014 - February 2015

\begin{tabular}{|c|c|c|c|c|c|}
\hline No & $\begin{array}{l}\text { Habitat characteristic } \\
\text { of HDM }\end{array}$ & $\begin{array}{c}\text { Number of } \\
\text { point } \\
\text { examined }\end{array}$ & $\begin{array}{c}\text { Percentage } \\
\text { positive } \\
\text { point }\end{array}$ & $\begin{array}{l}\text { The average of mites } \\
\text { density / g of dust }\end{array}$ & $\begin{array}{l}\text { Distribution of } \\
\text { HDM }(\%)\end{array}$ \\
\hline \multirow{7}{*}{1} & \multicolumn{5}{|l|}{$\begin{array}{l}\text { Densely populated } \\
\text { Residential }\end{array}$} \\
\hline & Carpet & 11 & 100.00 & $73 \pm 61.69$ & 23.94 \\
\hline & Seat & 19 & 94.74 & $66.85 \pm 140.06$ & 21.92 \\
\hline & Floor & 19 & 94.74 & $65.68 \pm 84.01$ & 21.54 \\
\hline & Furniture & 20 & 85.00 & $61.45 \pm 164.55$ & 20.15 \\
\hline & Bed & 15 & 80.00 & $38 \pm 43.51$ & 12.46 \\
\hline & Total & 84 & 90.47 & & 100 \\
\hline \multirow{7}{*}{2} & \multicolumn{5}{|l|}{ Residential complexes } \\
\hline & Carpet & 9 & 100.00 & $51.88 \pm 43.52$ & 33.71 \\
\hline & Floor & 20 & 55.00 & $40.2 \pm 59.95$ & 26.11 \\
\hline & Furniture & 20 & 85.00 & $32.3 \pm 42.81$ & 20.98 \\
\hline & Seat & 20 & 95.00 & $22.8 \pm 27.32$ & 14.81 \\
\hline & Bed & 20 & 75.00 & $6.75 \pm 8.11$ & 4.38 \\
\hline & Total & 89 & 79.78 & & 100 \\
\hline
\end{tabular}


positive, with average $38 \pm 43.51 \mathrm{mites} / \mathrm{g}$ dust) and in residential complex (75\% positive with average $6.75 \pm$ $8.11 \mathrm{mites} / \mathrm{gr}$ dust).

Habitat distribution of HDM in densely populated residential area was found from high to low, respectively in carpet $(23.94 \%)$, seat $(21.92 \%)$, floor $(21.54 \%)$, furniture $(20.15 \%)$ and bed $(12.46 \%)$, meanwhile in residential complex was found in carpets $(33.71 \%)$, floors $(26.11 \%)$, furniture $(20.98 \%)$, seat $(14.81 \%)$ and bed (4.3\%). In addition, HDM were also found on other household furniture, such as jars, paintings, vases, windows etc. This is because household furniture was not daily cleaned therefore so much dust remains as well as many organic ingredients available that provide abundant food for HDM. Santoso [8] reported in Denpasar Bali, all of 14 houses of examined asthma patients were all found positive of HDM. A total of 12 house samples were found Dermatophagoides sp. mixed with other HDM, with densities ranging between 20-104 mites/g of dust. In Mexico (Latin America) HDM density (B. Tropicalis) can reach to $8.934 \mathrm{mites} / \mathrm{g}$ of dust [14].

\subsection{The Density and Distribution of HDM at The Transitional Shelter Areas}

The density and distribution of HDM in transitional shelter areas are presented in Table 4 . In the guest house, HDM were found in furniture $(0.15 \pm 0.36$ mites/g of dust $)$, obtained from 2 rooms (16.67\%) a positive of the 12 rooms checked. Meanwhile no HDM found on the bed and the floor. In this place, although the temperature and the humidity are very supportive for the breeding of HDM, but the presence and density of HDM in this area was low. This was because the homestead floor is always being mopped and cleaned regularly every day, as well as cleaning the mattress, pillow, bed sheets and pillowcases.

In the boarding school, the highest density of HDM was found in the furniture $(8 \pm 13.64 \mathrm{mites} / \mathrm{g}$ of dust), followed by the bed $(6.73 \pm 7.00 \mathrm{mites} / \mathrm{g}$ of dust $)$, and the floor $(6.53 \pm 7.05$ mites $/ g$ of dust $)$. Furthermore, the highest density of HDM in boarding house was found in the room's furniture $(48.54 \pm 29.26 \mathrm{mites} / \mathrm{g}$ of dust) followed by the floor $(30.62 \pm 22.45 \mathrm{mites} / \mathrm{gr}$ of dust), and the bed $(14.15 \pm 10.89 \mathrm{mites} / \mathrm{g}$ of dust). Meanwhile, in student dormitories the highest HDM was found in rooms furniture $(13.47 \pm 17.47$ mites/g of dust) followed by the bed $(13.13 \pm 20.32 \mathrm{mites} / \mathrm{g}$ of dust), and the floor (11.72 $\pm 22.07 \mathrm{mites} / \mathrm{g}$ of dust).

The high density of HDM at boarding school, guest house and boarding house compared to the guest house were because of most goods contained in the rooms are not always being cleaned. HDM breed properly in the settlements where many used and unused materials piled inside the houses for a long time, providing abundant organic materials as food intake for HDM. The HDM also can flourish on the bed because there are a lot of available scale or skuama produced by human $(0.5-1 \mathrm{~g} /$ day $)$ as mite food sources. Additionally, bedroom furniture consisting of a mattress, blankets, curtains and bed linen contains many fibers that are easier to accommodate dust than other home furnishings.

Table 4 The density and distribution of TDR in transitional shelter areas of Bogor from October 2014 - February 2015

\begin{tabular}{|c|c|c|c|c|c|}
\hline No & $\begin{array}{c}\text { Habitat characteristic of } \\
\text { HDM }\end{array}$ & $\underset{\text { examined }}{\sum \text { point }}$ & $\begin{array}{c}\text { Percentage } \\
\text { positive } \\
\text { point }\end{array}$ & $\begin{array}{c}\text { The average of density } \\
\text { mites/gr of dust }\end{array}$ & $\begin{array}{l}\text { Distribution of } \\
\text { HDM (\%) }\end{array}$ \\
\hline \multirow[t]{5}{*}{1} & \multicolumn{5}{|l|}{ Guest house: } \\
\hline & furniture & 12 & 16.67 & $0.15 \pm 0.36$ & 100 \\
\hline & bed & 12 & 0.00 & $0 \pm 0$ & 0 \\
\hline & floors & 12 & 0.00 & $0 \pm 0$ & 0 \\
\hline & Total & 36 & 5.55 & & 100 \\
\hline \multirow[t]{5}{*}{2} & \multicolumn{5}{|l|}{ Boarding schools: } \\
\hline & furniture & 15 & 66.67 & $8 \pm 13.64$ & 37.62 \\
\hline & bed & 15 & 60.00 & $6.73 \pm 7.00$ & 31.66 \\
\hline & floors & 15 & 80.00 & $6.53 \pm 7.05$ & 30.72 \\
\hline & Total & 45 & 68.88 & & 100 \\
\hline \multirow[t]{5}{*}{3} & \multicolumn{5}{|l|}{ Boarding houses: } \\
\hline & furniture & 13 & 92.31 & $48.54 \pm 29.26$ & 52.02 \\
\hline & floors & 13 & 84.62 & $30.62 \pm 22.45$ & 33.81 \\
\hline & bed & 13 & 76.92 & $14.15 \pm 10.89$ & 15.17 \\
\hline & Total & 39 & 84.62 & & 100 \\
\hline \multirow[t]{5}{*}{4} & \multicolumn{5}{|l|}{ Student dormitories: } \\
\hline & furniture & 56 & 69.65 & $13.47 \pm 17.47$ & 35.17 \\
\hline & bed & 56 & 73.22 & $13.13 \pm 20.32$ & 34.26 \\
\hline & floors & 56 & 64.29 & $11.72 \pm 22.07$ & 31.58 \\
\hline & Total & 168 & 69.05 & & 100 \\
\hline
\end{tabular}


Research conducted by Mcrae et al. [22] at the student hostel in Dunedin (New Zealand), showed that the density of HDM more commonly found on the floor compared to the bed. This was because the sheets used in dormitory were regularly washed by hot water and washing machine. Besides that, the HDM on bed were only found on the mattress which used for more than one year, and no HDM finding at less than one year mattress.

There was significantly correlation between humidity and temperatures to the infestation of HDM in all types of settlements. High humidity cause the high of HDM density, seen from $\mathrm{P}$ value $(\mathrm{P}=0.026 \leq \alpha=0.05)$ very high level of correlation, and characterized by value of $\mathrm{R}=0.769$, belonged to the strong category. On the contrarily, high temperature cause the low of HDM density, seen from $\mathrm{P}$ value $(\mathrm{P}=0.003 \leq \alpha=0.01)$ very high level of correlation, and characterized by value of $\mathrm{R}=0.895$ included in the strong category.

\section{CONCLUSION}

Total of 1,256 HDM were identified on settlement areas in Bogor. The result showed there were 10 types of HDM, i.e Blomia tropicalis (45.34\%), Dermatophagoides pteronyssinus (17.45\%), Cheyletidae (15.62\%), Blomia spp. (8.61\%), Mesostigmata (7.17\%), Dermatophagoides farinae $(3.67 \%)$, Oribatida $(0.56 \%)$, Acaridae $(0.32 \%)$, Tyrophagus spp. (0.16\%), Lepidoglipus destructor $(0.08 \%)$. The highest density of HDM on housing was found on the carpet, both in densely populated residential $(23.94 \%)$ and residential complex (33.71\%). At temporary shelter, HDM mostly found on the household goods, at guest houses (100\%), boarding schools (37.62\%), boarding houses $(52.02 \%)$ and student dormitories $(35.17 \%)$. There was significant correlation between humidity and temperatures against the infestation of HDM in all types of settlements.

\section{ACKNOWLEDGMENT}

We are grateful to all staff of Entomology Laboratory, Division of Parasitology and Medical Entomology, Department of Animal infectious Diseases and Veterinary Public Health, Faculty of Veterinary Medicine, IPB University, Bogor Indonesia, for their continuous support and encouragement.

\section{REFERENCES}

[1] M.J. Collof, F.T. Spieksma, Pictorial keys for the identification of domestic mites Clin. Exp. Allergy, 22 (1992) 823-830

[2] G.W. Krantz and D.E. Walter, A Manual of Acarology, America: United States of America, 2009.
[3] A. Warner, S. Bostrom, C. Moller, N.I.M. Kjelman, Mite fauna in the home and sensitivity to house-dust and storage mites, Allergy, 54 (1999) 681-690

[4] E.M.S. Milian, A.M. Diaz, Allergy to house dust mites and asthma, PRHSJ, 23(1) (2004) 47-57

[5] G. Larry, L.G. Arlian, S. Marjorie, J.S.Morgan and B.S. Neal, Dust mite allergens: ecology and distribution, Curr. Allergy Asthma Rep. 2(5) (2002)401-411

[6] W.R. Thomas, Geography of house dust mite allergen, J. Allergy Immunol. 28 (2010) 211-24

[7] I.R. Baratawidjaja, P.P. Baratawidjaja, and A. Darwis, Mites in Jakarta homes, Allergy, 53(12) (1998) 1226-1227

[8] H. Santoso, The value of a single skin prick testing for specific IgE Dermatophagoides pteronyssinus to distinguish atopy from nonatopic asthmatic children in the tropics, Asian Pac. J. Allergy Immunol. 16 (1998) 69-74

[9] U.K. Hadi and S. Soviana, Ektoparasit; Pengenalan, Diagnosa dan Pengendaliannya, Bogor: IPB Press, 2010

[10] A.L. Roden, Extraction Efficiency and Identification Guide to Common House Dust and Storage Mites, Georgia: Graduate Faculty of the University of Georgia in Partial Fulfillment of the Requirements for the Degree, 2012

[11] E.P. Odum, Dasar-Dasar Ekologi Terjemahan oleh Tjahjono Samingan Fundamentals of Ecology, Yogyakarta: UGM Press, 1993

[12] C.J. Krebs, Ecology The Experimental Analysis of Distribution and Abundance Third Edition, New York: Harper and Row Publishers, 1987

[13] [BMKG] Badan Meteorologi dan Geofisika (The Meteorology, Climatology and Geophysics Agency, abbreviated BMKG) Kabupaten Bogor, Data Klimatologi, Bogor: BMGKK, 2015

[14] B.E. Stanaland, E. Fernandez-Caldas, C.M. Jacinto, W.L. Trudeau and R.F. Lockey, Sensitization to Blomia tropicalis: skin test and cross-reactivity studies, J. Allergy Clin. Immunol. 94(3) (1994) 52-457

[15] L.G. Arlian and T.A.E. Platts-Mills, The biology of dust mites and the remediation of mite allergens in allergic disease, J. Allergy Clin. immunol. 107(3) (2002) 406-413

[16] E.C. Liao, C.M. Ho, M.Y. Lin and J.J. Tsai, Dermatophagoides pteronyssinus and Tyrophagus putrescentiae allergy in allergic rhinitis caused by 
genome, transcriptome, and microbiome of Dermatophagoides farinae reveal a broad spectrum of dust mite allergens, J. Clin. Immunol. 135(2) (2015)539-548

[20] L.G. Arlian and J.S Dippold, Development and fecundity of Dermatophagoides farinae (Acari: Pyroglyphidae) J. Med. Entomol. 33(2) (1996) 257-260

[21] W. Danny, D.V.M Scott, T. Robert and J.R. Horn Zoonotic Dermatoses of Dogs and Cats Veterinary Clinics North America, 17(1) (2015) 117-144

[22] W.M. Mcrae, E.M. Flannery, J.O. Cowan, C.R.Mclachlan, S.R.W. Herbison, J Crane and C.S. Wong, House dust mite allergen levels in University student accommodation in Dunedin, NZMJ, 115(1157) 20021-6 